\title{
Conventional and Non-conventional Smoking on Microbial Quality and Histamine of Ikan Fufu (Smoked Fish)
}

\author{
Sitti Salmiyah A.Bahruddin ${ }^{1}$, dan Fahmi Abdul Hamid ${ }^{2}$ \\ Poltekkes Kemenkes Ternate Jl. Tanah Tinggi ; Tanah Tinggi Bar ; Ternate Sel ; Kota Ternate ; Maluku \\ Utara
}

\begin{abstract}
Fish is a commodity with high nutritional value. The content of this nutritional value causes fish to be easy to decompose. Therefore, it is necessary to develop and process skipjack fufu (smoked skipjack) fish that improve the quality of smoked skipjack tuna (smoked skipjack) chemically, microbiologically, and with low histamine content. The purpose of this study was to determine the chemical, microbiological, and histamine quality of smoked fish with conventional and non-conventional smoking. This type of research was a quantitative study with a randomized block design. This research is a laboratory experiment with two treatments, namely conventional and non-conventional methods equipped with three replications and three blocks.

The results of the test on the third day (H3) and the ninth day (H9) of storage showed that there was no growth of Salmonella sp. and Vibrio cholera in smoked fish samples with conventional (P2) and nonconventional (P1) smoking techniques. There were differences in non-conventional and conventional smoking on the histamine content in smoked fish.

Conclusion. There was no growth of Salmonella sp and Vibrio cholera in smoked fish. There is a difference in the histamine content of conventional (P2) and non-conventional (P1) smoking techniques in smoked fish.
\end{abstract}

Keywords: Chemical quality, histamine, microbial, smoked fish

\section{Introduction}

Fish is a fish product commodity with high nutritional value. The content of high nutrition value causes fish to be rotten easily. High water and protein content lead to free amino acids used for the metabolism of proliferating microorganisms that produce ammonia products, biogenic amines, organic acids, ketones, and sulfur components (Radjawane, Darmanto, \& Swastawati, 2016). Skipjack tuna (Katsuwonus pelamis) is a type of marine fish commonly consumed by the Indonesian people and enriched by a high protein content which is good for the human body (Kekenusa, Watung, \& Hatidja, 2012).

The number of captured fisheries products in North Maluku Province is 254,877 tons which processed products have only reached 25,292 tons (BPS 2017). Meanwhile, data on fish trade out of Ternate City to Bitung, Jakarta, Makassar, and Batam only about 1,076,031 kilograms in good condition. Proper processing of fufu (smoked skipjack tuna) can increase the economic value and quality of the fishery commodity, which has an impact on the PAD of North Maluku and the City of Ternate.

Tuna is one type of fish that immediately decayed due to the activity of microorganisms (if left at room temperature). Spoiled tuna will cause histamine poisoning that shows the emergence of allergy symptoms (Fendjalang, 2018). This poisoning will usually arise due to the high levels of histamine found in the fish we consume. Histamine poisoning will be dangerous if someone consumes fish with a histamine content of 50 $\mathrm{mg} / 100 \mathrm{~g}$ of fish (Amir, Metusalach, \& Fahrul, 2018). The cause of the high histamine content in raw materials is the sanitary conditions during the handling of fish on board and also the temperature in maintaining the quality of the fish (Joshi \& Bhoir, 2011).

To maintain the quality and shelf life of skipjack tuna, the people of North Maluku make it in smoked fish form. Smoked fish in North Maluku is known as fufu fish. The community is like this because it has a good 
taste and a distinctive smell (Hamid, 2018). UV detector is one the factors that determine histamine concentrations with a high-performance liquid chromatography (Peivasteh-Roudsari et al., 2020). Thus, efforts are needed to develop and process skipjack tuna fufu (smoked skipjack) which can improve the quality of tuna fufu (smoked skipjack) chemically, microbiologically, and histamine content.

In Ternate, the processing of Smoked skipjack still uses the traditional smoking technique, the raw material for burning using a coconut belt. The processing process requires a large amount of fuel and requires a long time in the fumigation process. Therefore, it is necessary to develop appropriate technology that is more efficient and effective in smoking raw materials the smoking time becomes shorter. Nowadays, the problem faced by producers is the need to develop an oven as a traditional smoking tool. It is considered safer, more effective, and efficient in processing smoked fish. Moreover, this oven uses less fuel than ordinary smoking. Furthermore, the smoking process is faster. A study proved that the smoked fish from the fabricated smoking kiln have a longer shelf-life than those from the commonly used drum oven (Magawata \& Musa, 2015).

From these descriptions and reviews, researchers are interested in researching with the title The Effect of Conventional and Non-Conventional Smoking on Microbiology and Histamine in Fufu Fish (Smoked Fish).

\section{Method}

This study aims: To know the difference between conventional and non-conventional smoking on microbiology and histamine in smoked fish.

This type of research is quantitative research with a randomized block design. The study is a laboratory experiment with two treatments: conventional and non-conventional smoking processes. There were three replications and three blocks. The process involved conducted in three stages. The first stage is to prepare two samples of 1000 grams of fresh skipjack fish each. The second stage is smoking using a FAVEN or conventional oven and ordinary traditional smoking or non-conventional smoking. The raw material for smoking uses a dry coconut belt. The third stage carried out microbiological analysis (Salmonella sp and Vibrio cholera) twice on day three and day six. Histamine analysis was carried out on day 3, day 6, day 9 , and day in pairs, respectively.

The study location was in the Nutrition Laboratory of the Ternate Health Polytechnic and the PT. Saraswanti Indo Genetech Bogor. It takes time from February to November 2019. Bluefin tuna is the study population. It is the most commonly used by producers as the base material of smoked fish.

\section{Result}

\section{a. Demographic Data}

Smoked fish used in this study was bluefin tuna obtained from fishermen with a catch age and stored for 1-2 days in a fresh state. Smoked fish samples consisted of two groups with three replications for histamine measurement, salmonella sp and vibrio colerae measurements were repeated twice. The sample codes for non-conventional smoking treatments were P1H3 (third day testing), P1H6 (sixth day testing), P1H9 (ninth day testing). Meanwhile, conventional smoking uses the sample code, namely P2H3 (third day testing), P2H6 (sixth day of testing), P2H 9 (ninth day of testing).

\section{b. Salmonella sp and Vibrio Cholerae}

Table.1 Results of Microbiological Testing of Salmonella sp in Conventional and Non-Conventional Smoked Fish

Note

\begin{tabular}{|c|c|c|}
\hline \multirow{2}{*}{$\begin{array}{c}\text { Day of } \\
\text { Testing }\end{array}$} & \multicolumn{2}{|c|}{ Salmonella $s p$} \\
\cline { 2 - 3 } & P1 & P2 \\
\hline H3 & Negative & Negative \\
\hline H6 & Negative & Negative \\
\hline
\end{tabular}

P1: Non-conventional smoked 


\section{P2: Conventional smoked}

Based on the results of the study in table 4.1, testing on the third day (H3) and the ninth day (H9) of storage showed that there was no growth of salmonella sp in smoked fish samples using conventional (P2) and nonconventional (P1) smoking techniques.

\section{c. Vibrio Cholerae}

Table 2 Test Results of Vibrio Cholerae on Conventional and Non-Conventional Smoked Fish

\begin{tabular}{|c|c|c|}
\hline \multirow{2}{*}{ Day of Testing } & \multicolumn{2}{|c|}{ Pibrio Cholerae } \\
\cline { 2 - 3 } & P2 & P1 \\
\hline H3 & Negative & Negative \\
\hline H6 & Negative & Negative \\
\hline
\end{tabular}

Note:

P1: Non-conventional smoked

P2: Conventional smoked

Based on the results of the study in table 4.2, on the third day of testing (H3) and the ninth day (H9) of storage there was no growth of Vibrio cholerae in smoked fish samples using Conventional (P2) and NonConventional (P1) smoking techniques.

\section{d. Kandungan Histamin}

Table 3 Histamine Test Results on Conventional and Non-Conventional Smoking Techniques Smoked Fish

\begin{tabular}{|c|c|c|l|}
\hline \multirow{2}{*}{$\begin{array}{c}\text { Day of } \\
\text { Testing }\end{array}$} & \multicolumn{2}{|c|}{ Histamine } & \multirow{2}{*}{$p$} \\
\cline { 2 - 3 } & $\mathrm{P} 1$ & $\mathrm{P} 2$ & \\
\hline $\mathrm{H} 3$ & 251.60 & 106.96 & \\
\hline $\mathrm{H} 6$ & 1040.81 & 524.65 & \multirow{2}{*}{0,026} \\
\hline H9 & 2602.91 & 2384.10 & \\
\hline Average & 1298.44 & 1004.24 & \\
\hline SD \pm & 1196.639 & 1210.550 & \\
\hline
\end{tabular}

Table 4.3 shows the third day of testing (H3) of storage of histamine content in smoked fish samples with non-conventional smoking techniques $(\mathrm{P} 1 \mathrm{H} 3)$ was $251.60 \mathrm{mg} / \mathrm{kg}$. While the results of the sixth day of storage (H6) showed an increased Histamine content in smoked fish samples with conventional smoking technique (P2H6) was $106.96 \mathrm{mg} / \mathrm{kg}$ and increased up to $2602.91 \mathrm{mg} / \mathrm{kg}$ on the ninth day (H9) of storage. The average histamine value on the third day (H3) to the ninth day (H9) was $1298.44 \mathrm{mg} / \mathrm{kg}$ with $\mathrm{SD} \pm 1196.639 \mathrm{mg} / \mathrm{kg}$. In contrast to the third day of testing (H3), histamine content in smoked fish samples with conventional smoking techniques (S2H3) was $106.96 \mathrm{mg} / \mathrm{kg}$. The test on the sixth day (H6) of storage of histamine content in smoked fish samples with conventional smoking techniques (P2H6) was 524.65 $\mathrm{mg} / \mathrm{kg}$ and increased to $2384.10 \mathrm{mg} / \mathrm{kg}$ on the ninth day (H9) of storage. Tilapia average on the third day (H3) to the ninth day (H9) was $1004.24 \mathrm{mg} / \mathrm{kg}$ with $\mathrm{SD} \pm 1210.550 \mathrm{mg} / \mathrm{kg}$.

\section{Pembahasan}

a. Effect of Conventional and Non-Conventional Smoking on the Content of salmonella sp in smoked fish Salmonella sp bacteria is a type of bacteria that belongs to the Enterobacteriaceae group. The results showed that conventional smoking different from non-conventional smoking on the content of salmonella sp in smoked fish. No salmonella sp was detected, presumably because it has been well-handled. In the processing stage, all food safety standards: the use of gloves and media for placing samples are provided in a sterile 
condition so that it helps in maintaining the quality of smoked fish. Factors that influence the contamination of salmonella sp bacteria, namely the application of poor sanitation and hygiene applied when producing smoked fish to the transportation and marketing process because of the high risk of contamination occurring at this stage of the production chain (Ekawati, Martini, \& Yuliawati, 2005).

The quality of smoked fish can be maintained because the process that is maintained properly, starting from the process of selecting fish, processing, distributing to the sales process, control, and standardized handling must be carried out because fish is a potential medium for growth (Amra, Ali, \& Hamid, 2018).

\section{b. The Effect of Conventional and Non-Conventional Smoking on the Content of Vibrio cholerae in Smoked Fish}

Mewengkang H.W (2010) stated that Vibrio Chorelae has an optimal growth temperature of $5^{\circ}-40^{\circ} \mathrm{C}$. At $50^{\circ} \mathrm{C}$. These bacteria cannot grow because the Vibrio cholerae bacteria cannot tolerate heat. Smoked skipjack tuna processed in hot smoke. It can kill Vibrio cholera because these bacteria are intolerant to heat, especially when the blade temperature is above $50^{\circ} \mathrm{C}$. The factor that causes smoked fish to be free of Vibrio cholera is because it is processed well. The treatment during processing where the fish stomach must be clean and the equipment used is sterile (Mewengkang, 2010). A study showed there was no Vibrio cholera in smoked fish that is properly processed (Hadinoto, Kolanus, \& Manduapessy, 2016).

\section{c. The Effect of Conventional and Non-Conventional Smoking on the Histamine Content in Smoked Fish}

Based on the results of statistical tests using the two-way ANOVA method in table 3.4, it shows that there are differences between conventional and non-conventional smoking on the histamine content of smoked fish with a significant level of p 0.0260 .05 . This difference is presumably because the technique of the conventional smoking produced heat equally in the smoking cabin to resulting a perfect level of maturity so that the water content in smoked fish is lower than non-conventional smoking. Water content is one of the important characteristics of foodstuffs, because water can affect the appearance, texture, and taste of foodstuffs (Mailoa, Lokollo, Nendissa, \& Harsono, 2019). The high and low water content in foodstuffs determines the freshness and durability of these foodstuffs, high water content results in easy bacteria and mold.

Based on the results of previous studies showed that the average value of the water content of conventional smoking on the first day to the ninth day was 44.2550 with $\mathrm{SD} \pm 2.68719$ and the average value for nonconventional was $45.8325 \%$ with $\mathrm{SD} \pm 1.94087$ which was below the standard of smoked fish water content. The standard value of smoked fish moisture content based on SNI (2013) is a maximum of 60-65\%.

The Indonesian National Standard for histamine content in smoked fish is $100 \mathrm{mg} / 100$ grams. The test data on the third day (H3) shows that the histamine content is still below the SNI standard, while on the sixth day (H6) and the ninth day (H9) it becomes $1040.81 \mathrm{mg} / \mathrm{kg}$ and $2602.91 \mathrm{mg} / \mathrm{kg}$ is above the standard.

Moisture content is an important parameter to determine the quality of smoked fish produced. The water content contained in smoked fish can affect the shelf life of smoked fish (Tumonda, Mewengkang, \& Timbowo, 2017). Because the water content is a medium for microbes to breed. Water content is an important parameter to determine the quality of smoked fish produced. The water content contained in smoked fish can affect the shelf life of smoked fish. The rapid increase in histamine levels is the result of the optimum growth of histamine-producing bacteria (Kanki, Yoda, Tsukamoto, \& Baba, 2007).

Another suspected factor is the handling during the smoked fish production process. Fish smoked by conventional smoking is carried out in a closed manner so that it does not come into contact with the open air, while non-conventional smoking techniques are carried out openly so that it is potentially contaminated with sources of histamine-producing bacteria. Handling is the main key in inhibiting the formation of histamine, discoloration, protein solubility, and microbial growth in skipjack tuna (Singh, Mittal, \& Benjakul, 2021). Smoking fish is intended to maintain freshness, in the sense that it still meets the requirements for human consumption by preventing the occurrence of fish spoilage. Fish smoking is one of the fish processing methods that combines the process of salting, heating and attaching the chemical components of smoking (Prasetyo, Darmanto, \& Swastawati, 2015). Incidence of histamine producing bacteria in all fish samples and their incidence can be minimized by implementation of more hygienic and sanitary conditions during handling and processing of fish based on the guidelines of FDA (Joshi \& Bhoir, 2011). 


\section{Conclusion}

a. Conclusion

1. There was no Salmonella sp. in conventional and non-conventional smoking of smoked fish

2. Vibrio cholera bacteria was not found in both conventional and non-conventional smoking of smoked fish

3. There is a difference between non-conventional and conventional smoking on the histamine content in smoked fish.

\section{b. Suggestion}

1. Conduct further research by conducting phytochemical analysis starting from the first day of research

2. Conducting further research by conducting microbiological testing on the raw materials used and testing smoked fish on the first day as a comparison.

3. Conducting further research in testing histamine-producing bacteria

\section{Acknoledgement}

Thanks to the Director of Ternate Health Polytechnic of Health Ministry that has funded the study. We also thank all parties who played a role in this article.

\section{References}

1. Amir, N., Metusalach, M., \& Fahrul, F. (2018). Mutu dan Keamanan Pangan Produk Ikan Asap di Kabupaten Bulukumba Provinsi Sulawesi Selatan. Agrikan: Jurnal Agribisnis Perikanan, 11(2), 15. https://doi.org/10.29239/j.agrikan.11.2.15-21

2. Amra, N., Ali, N. M., \& Hamid, F. A. (2018). Identifikasi Bakteri Escherichia Coli(E.Coli) Dan Vibrio sp Pada Ikan Asap di Kota Ternate. Jurnal Kesehatan, 3(1), 1-6.

3. Ekawati, P., Martini, \& Yuliawati, S. (2005). Kontaminasi Staphylococcus aureus Pada Ikan Asap di Tingkat Produsen dan Penjual di Semarang. Jurnal Kesehatan Masyarakat Indonesia, 2(2), 7076.

4. Fendjalang, S. N. M. (2018). Analisis Kimia Ikan Tuna Asap Pada Beberapa Pasar Tradisional Di Tobelo, Kabupaten Halmahera Utara. Prosiding Seminar Nasional KSP2K, 1(2), 174-178.

5. Hadinoto, S., Kolanus, J. P. M., \& Manduapessy, K. R. W. (2016). The Characteristic of Quality Skipjack Tuna (Katsuwonus pelamis) Liquid Smoke Using Liquid Smoke from Coconut Shell. Majalah Biam Kementerian Perindustrian, 12(1), 20-26.

6. Hamid, F. A. (2018). Perilaku Keamanan Pangan Dengan Kualitas Ikan Asap Di Pasar Kota Ternate. Jurnal Riset Kesehatan, 7(1), 51-56.

7. Joshi, P. A., \& Bhoir, V. S. (2011). Study of Histamine Forming Bacteria in Commercial fish samples of Kalyan city. International Journal of Current Scientific Research, 1(2), 39-42.

8. Kanki, M., Yoda, T., Tsukamoto, T., \& Baba, E. (2007). Histidine Decarboxylases and Their Role In Accumulation of Histamine In Tuna and Dried Saury. Applied and Environmental Microbiology, 73(5), 1467-1473. https://doi.org/10.1128/AEM.01907-06

9. Kekenusa, J. S., Watung, V. N. ., \& Hatidja, D. (2012). Analisis Penentuan Musim Penangkapan Ikan Cakalang (Katsuwonus Pelamis)di Perairan Manado Sulawesi Utara. Jurnal Ilmiah Sains, 12(2), 112-119. https://doi.org/10.35799/jis.12.2.2012.704

10. Magawata, I., \& Musa, T. (2015). Quality Characteristics Of Three Hot-Smoked Fish Species Using Locally Fabricated Smoking Kiln. International Journal of Fisheries and Aquatic Studies, 2(5), 88-92.

11. Mailoa, M. N., Lokollo, E., Nendissa, D. M., \& Harsono, P. I. (2019). Karakteristik Mikrobiologi dan Kimiawi Ikan Tuna Asap. Jurnal Pengolahan Hasil Perikanan Indonesia, 22(1), 89-99. Diambil dari https://core.ac.uk/download/pdf/291864206.pdf

12. Mewengkang, H. W. (2010). Identifikasi Vibrio Sp Pada Gonad Ikan Cakalang (Katsuwonus 
Pelamis L). Jurnal Perikanan Dan Kelautan Tropis, 6(1), 18 . https://doi.org/10.35800/jpkt.6.1.2010.109

13. Peivasteh-Roudsari, L., Rahmani, A., Shariatifar, N., Tajdar-Oranj, B., Mazaheri, M., Sadighara, P., \& Khaneghah, A. M. (2020). Occurrence Of Histamine In Canned Fish Samples (Tuna, Sardine, Kilka, And Mackerel) From Markets In Tehran. Journal of Food Protection, 83(1), 136141. https://doi.org/10.4315/0362-028X.JFP-19-288

14. Prasetyo, D. Y. B., Darmanto, Y. S., \& Swastawati, F. (2015). Efek Perbedaan Suhu Dan Lama Pengasapan Terhadap Kualitas Ikan Bandeng (Chanos Chanos Forsk) Cabut Duri Asap. Jurnal Aplikasi Teknologi Pangan, 4(3), 94-98. https://doi.org/10.17728/jatp.v4i3.134

15. Radjawane, C., Darmanto, Y. S., \& Swastawati, F. (2016). Kajian Kandungan Histamin Ikan Cakalang (Katsuwonus pelamis) Segar Dan Asap Pada Sentral Pengolahan Ikan Asap di Kota Ambon. Prosiding Seminar Nasional Kelautan Universitas Trunojoyo Madura, 316-320.

16. Singh, A., Mittal, A., \& Benjakul, S. (2021). Undesirable Discoloration In Edible Fish Muscle: Impact Of Indigenous Pigments, Chemical Reactions, Processing, And Its Prevention. https://doi.org/10.1111/1541-4337.12866

17. Tumonda, S., Mewengkang, H. W., \& Timbowo, S. M. (2017). Kajian Mutu Ikan Cakalang (Katsuwonus Pelamis L) Asap Terhadap Nilai Kadar Air Dan Ph Selama Penyimpanan. Media Teknologi Hasil Perikanan, 5(2), 64. https://doi.org/10.35800/mthp.5.2.2017.14937 